\title{
Syntax Outranks Phonology: Evidence from Ancient Greek
}

0 Introduction

What influence do syntax and phonology have on one another? Two types of answer to this question appear in the literature. The consensus view is probably best expressed by Zwicky \& Pullum (1986; see also Myers 1987; Vogel \& Kenesi 1990), who claim that the relation is one way: although phonological phrasing above the word is affected by syntactic structure, syntax itself is phonology-free. The result is guaranteed in a derivational model of grammar by ordering all syntactic rules before any phonological (prosodic and segmental) rules:

(1) Syntax derivationally precedes phonology (rule-based model)

Zec \& Inkelas (1990) have argued that this sort of model is overly restrictive and does not allow for cases where prosodic restrictions partially determine syntactic well-formedness. They propose a constraint-based model in which syntax and phonology interact bidirectionally: ${ }^{1}$

(2) Syntax constrains prosody and vice versa (constraint-based model)

I'll argue in this paper that (1) and (2) are not good ways to model the syntaxphonology interface. (1) does not allow enough prosodic influence on syntax (as argued by Zec \& Inkelas) and (2) allows far too much. (1) is able to capture the general case (phonology has little influence on syntax) but not the exceptional cases (it does have some); conversely, grammars conforming to (2) are able to capture the exceptional cases (some influence) but fail to capture the general case (not very much). 
I will show that all clear cases of prosodic influence on syntax in the literature involve pairs of syntactic constructions, one of which is ruled out by a prosodic constraint. That is, prosody chooses between structures which are equally wellformed syntactically. In this paper I'll try and substantiate this generalization and argue that an account in terms of Optimality Theory (Prince \& Smolensky 1993) provides a ready solution for it. In particular, I'll argue that components of the grammar are ranked with respect to one another, much as constraints are ranked with respect to one another in Optimality Theory. In short, I'll argue that (3) best represents the influence of syntax and phonology on one another:

(3) Syntactic constraints outrank prosodic constraints

To make the issues clearer I begin with illustrative cases from English and German. Consider the pair of NPs in (4):

(4) a. The [video [of Macbeth]]

b. The [[Macbeth] video]

(4a) has a postnominal PP modifier whereas (4b) has a prenominal NP modifier; both are fully grammatical. But if we replace Shakespeare's Macbeth with Joyce's The Dead, the second construction is ill-formed:

(5) a. The [video [of The Dead]]

b. *The [[The Dead] video]

(5b) is syntactically well-formed but prosodically ruled out because of the sequence $*$ the the. The role of the constraint that rules out $*$ the the is to choose between syntactic structures which are equally well-formed: there is a grammatical way to say $(5 b)$ and that is $(5 a) .^{2}$ 
Now consider a similar case from German. German syntax readily admits strings of adjacent homophonous function words as in (6):

(6) die, die die Blumen gekauft haben those who the flowers bought have 'those who have bought the flowers'

(7) daß das das Problem ist that this the problem is 'that this is the problem'

(6) and (7) are fully grammatical. What accounts for the difference between the acceptability of (6) and (7) versus the marginality of (5b) is that German offers no simple alternatives to the constructions above. There is no way to postpose the relative clauses or the noun phrases they contain such that the various die's and das's won't occur next to one another. ${ }^{3}$ In (6) and (7) the phonology does not have a chance to decide between two well-formed syntactic alternatives and has no effect on grammaticality; in (5) the phonology decides between two equally well-formed syntactic structures and decisively rules in favor of the one that violates the phonology least. Prosody determines well-formedness if and only if syntax does not.

Neither (1) nor (2) has this as a natural result. But the model in (3) does because the role of dominated constraints in Optimality Theory (OT) is precisely to select between candidates that are not ranked by higher-ranking constraints (Prince \& Smolensky 1993). The English data may then be analyzed as follows: the Macbeth data violate no constraints, syntactic or phonological, and are both well-formed, as shown in the first tableau in (8). 
(8) English

\begin{tabular}{|c|c|c|}
\hline & SYNTAX & PHONOLOGY \\
\hline ( the 'Macbeth' video & & \\
\hline (] the video of 'Macbeth' & & \\
\hline
\end{tabular}

\begin{tabular}{|r|c|c||}
\hline & SYNTAX & PHONOLOGY \\
\hline the 'The Dead' video & & $* !$ \\
\hline$\square$ the video of 'The Dead' & & \\
\hline
\end{tabular}

The data for The Dead differ in that the first phrase violates something in the phonology while the second does not. The second wins and is thus the (only) grammatical candidate.

The German data is different because the syntax produces only a single acceptable form:

(9) German

\begin{tabular}{||r|c|c||}
\hline & SYNTAX & PHONOLOGY \\
\hline$\square$ daß das das Problem ist & & $*$ \\
\hline daß Problem das ist das & $* !$ & \\
\hline
\end{tabular}

Scrambling the formatives to satisfy the phonology is worse than having the offending phonological string because syntactic constraints are ranked above phonological ones. The opposite ranking would make something like $*_{\text {daß }}$ Problem das ist das the grammatical output; the claim of this paper is that such a ranking is impossible in natural language.

The rest of the paper proceeds as follows. Section 1 lays out the prosodic background to the discussion and claims that the prosodic hierarchy (Selkirk 1986; Hayes 1989; Nespor \& Vogel 1986) is itself best understood as a result of syntax outranking prosody. 
Section 2 introduces a phonological constraint, antihomophony, of Ancient Greek similar to the one behind the English and German data above: the constraint serves only to rule out one of two competing syntactic constructions, as predicted by (3) but not by (1) or (2).

Section 3 looks at how this prosodic constraint interacts with the morphology. Here we find that antihomophony actually forces the appearance of structures that are morphologically ill-formed, suggesting that prosodic constraints are ranked above morphological constraints in Ancient Greek.

Section 4 looks at related phenomena in Japanese, Italian, English and SerboCroatian and arrives at the same conclusion: syntax outranks prosody and prosody outranks morphology.

Section 5 considers how the derivational and bi-directional constraint models in (1) and (2) might account for all of this and concludes that (3) gives a more natural explanation for the observed phenomena.

\section{The prosodic hierarchy}

I assume here the theory of prosody developed in Selkirk (1986), an end-based theory of prosodic domains in which the edges of prosodic domains (Phonological Word, Phonological Phrase) are defined by the edges of syntactic domains $\left(\mathrm{X}^{0}, \mathrm{XP}\right)$; but the account offered here is also compatible with the approach begun by Hayes (1989) and furthered by (Nespor \& Vogel 1986). ${ }^{4}$ We can characterize the major prosodic domains of Ancient Greek as follows, where $\mathrm{X}$ ranges over the lexical categories noun, verb and adjective, function words and 
their projections being invisible in the mapping of syntax to prosody (Selkirk 1984).

$$
\begin{array}{ll}
\text { Phonological Word }]= & \left.\mathrm{X}^{0}\right] \\
\text { Phonological Phrase] }= & \mathrm{XP}]
\end{array}
$$

That is, a Greek utterance has as many phonological words as it has lexical items and the right edge of each phonological word is coterminus with the right edge of a lexical item; likewise, ceteris paribus, for phonological phrases and maximal projections. A phrase like (11) receives the prosodic constituency shown in (12):

(11) apò t-ées arkh-ées]N t-ées metabás-eoos]NP from the $\mathrm{g}_{\mathrm{f}} \mathrm{f}$ beginning $\mathrm{g}: \mathrm{f}$ the $\mathrm{g}_{\mathrm{f}}$ change $\mathrm{g}: \mathrm{f}$ 'from the beginning of the change' A.Poet 2.1455b 28

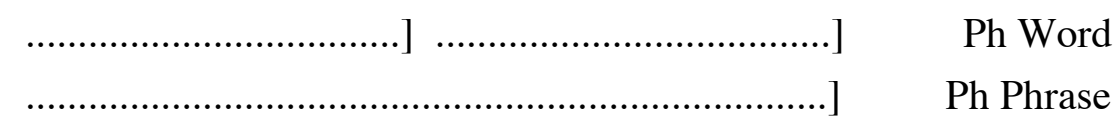

Prosodically dependent words in Greek are traditionally called appositives. The standard list includes articles, prepositions, relative pronouns, conjunctions, anaphoric pronouns, negatives and enclitics (Fränkel 1960, 142) - ie, Selkirk’s class of function words. Evidence that appositives formed phonological words with following content words comes from four sources: vowel coalescence, nasal assimilation, poetic meter and inscriptions.

Vowel coalescence (Haas 1988) merges the features of adjacent vowels within a prosodic word: this occurs within words (13) and across the boundary of a function word and a content word (14) with which it is phrased; but it does not occur across the boundary of two content words.

(13) Vowel Coalescence (within word) deelo-omen $\quad \rightarrow \quad$ [deelóumen] $(\mathrm{o}+\mathrm{O}=\mathrm{ou})$ 
reveal-1 pl

tima-ete $\quad \rightarrow \quad$ [timáate $\quad(\mathrm{a}+\mathrm{e}=\mathrm{aa})$

honor-2 pl

(14) Vowel Coalescensce (function word + content word)

$\begin{array}{llll}\begin{array}{l}\text { to ónoma } \\ \text { the name }\end{array} & -> & {[\text { toúnoma }]} & (\mathrm{o}+\mathrm{o}=\mathrm{ou}) \\ \begin{array}{l}\text { hà egoó } \\ \text { which I }\end{array} & -> & \text { [haagoó }] & (\mathrm{a}+\mathrm{e}=\mathrm{aa})\end{array}$

Nasal Assimilation, in which a dental nasal takes on the place features of a following stop, has the same domain of application: word-internally (15), between a function word and a content word (16), but never between two content words.

(15) Nasal Assimilation (within word)

$$
\begin{array}{lll}
\text { en-piin-oo } & -> & \text { [empiínoo] } \\
\text { in-drink-1 pres } & & \\
\begin{array}{l}
\text { en-khe-oo } \\
\text { in-pour-1 pres }
\end{array} & -> & \text { [eNkhéoo] }
\end{array}
$$

(16) Nasal Assimilation (function word + content word)

$\begin{array}{lll}\begin{array}{l}\text { teen polin } \\ \text { the city }(\mathrm{acc})\end{array} & -> & \text { [teèmpélin] } \\ \begin{array}{l}\text { ton kalon } \\ \text { the good }(\mathrm{acc})\end{array} & -> & \text { [tòNkalón] }\end{array}$

Additional evidence for the phonological dependence of Greek function words on following content words comes from their behavior in meter (Fränkel 1960; Bulloch 1970; Devine \& Stephens 1978, 1981, 1983). The evidence is based on the observation that word-breaks are preferred at some points in a line (caesurae) and dispreferred at others (bridges). Crucially the notion 'word-break' includes 
the break between two content words but not the break between a function word and another word, showing that function words are prosodically dependent.

The final type of evidence for the general dependence of function words comes from epigraphy. Most Ancient Greek inscriptions included no word-breaks at all. But a number of inscriptons put word breaks at the right edges of content words, writing function words as part of the following word: eg, ESGEEN for es 'into' geen 'country.' Again, this strongly suggests that these function words were prosodically dependent on what followed.

Not all function words in Greek were proclitic: the language contained a small set of Directional Clitics as well, function words whose direction of cliticization must be lexically listed (Nespor \& Vogel 1986). This set included tonally dependent function words (so-called enclitics such as te 'and' or ge 'indeed') as well as tonally independent function words (so-called postpositives such as dé 'and' or gár 'for'). ${ }^{5}$ All evidence - segmental, metrical and epigraphic-points to these words forming the same type of constituent with their hosts that rightleaning function words form with theirs; nor do these words exhibit any special syntactic behavior which might motivate a special syntactic consitutency. I won't discuss Directional Clitics further here (they play no role in what follows) except to note that they must be listed as exceptions to the constraints which govern the formation of prosodic consitutents.

Returning now to the general dependence of phonological phrasing on syntax, it should be clear that it is consistent with the claim that syntactic constraints outrank phonological constraints (3). The central observations in this area are (i) that (left or right) syntactic and prosodic edges are aligned and (ii) that syntactic 
edges are invariant. That is, alignment forces prosodic edges to align with syntactic edges, never the reverse.

The Greek phrasing algorithms in (10) can be recast as two (ranked) constraints. The first (17) requires that the right edge of a $\mathrm{X}^{0}$ coincide with the right edge of a phonological word; the second requires the same for XPs and phonological phrases:

(17) $\operatorname{ALign}\left(X^{0}, R\right.$, PRWORD, R)

Align (XP, R, PRPhrASE, R)

The dominance of syntax over prosody in (17) is clear once we realize that the equivalence relations are definitions for prosodic words and phrases in terms of $\mathrm{X}$ and XP; they are not, however, definitions for $\mathrm{X}$ and XP in terms of prosodic words and phrases. A further constraint, PARSE $\square$, requires that syllables be prosodically licensed (Itô 1986, 1989; Prince \& Somolensky 1993; McCarthy \& Prince 1993):

(18) PARSE $\square$ : syllables belong to prosodic words In what follows I'll refer to the constraints in (17) jointly as ALIGN and to (18) simply as PARSE. Given the right-branching syntactic structure in (19), we may consider how different candidate parses fare with respect to the ALIGN and PARSE constraints. 
(19)

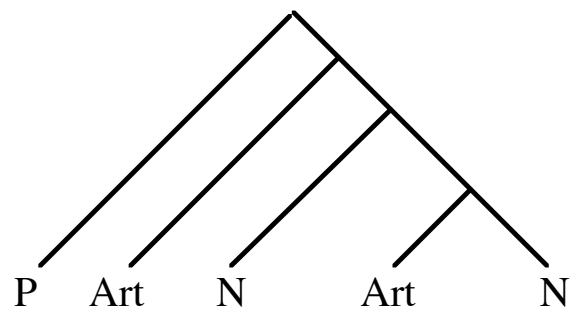

apò tées arxhées tées metabáseoos

from the beginning the change

'from the beginning of the change'

The first candidate in (20) is not optimal because it contains a lexical word (arkhées 'beginning') whose right edge does not coincide with the right edge of a phonological word. The second candidate is out because it contains a phonological word (apó 'from') whose right edge does not align with the right edge of a lexical word. The third candidate fails because it contains unparsed material, leaving the fourth candidate as the optimal one.

(20)

\begin{tabular}{|c|c|c|}
\hline & ALIGN & PARSE \\
\hline (apò tées arkhées tées metabáseoos) & $* !$ & \\
\hline (apò) (tées arkhées) (tées metabáseoos) & *! & \\
\hline apò (tées arkhées) (tées metabáseoos) & & $* !$ \\
\hline $\begin{array}{r}\text { (apò tées arkhées) (tées } \\
\text { metabáseoos) }\end{array}$ & & \\
\hline
\end{tabular}

\section{Antihomophony and syntax}

I turn now to the central data of this article, in which a prosodic constraint rules out an otherwise acceptable syntactic construction. The grammar of Ancient Greek prohibits adjacent homophones within a phonological word. 
Morphological effects of this constraint will be given in section 3. The syntactic effects are the topic of the present section.

Consider the center-embedded noun phrases in (21) and (22). ${ }^{6}$ Each begins with a definite article (téen, tá) that is immediately followed by the definite article for the subordinated NP (tóu, tóon). In (21) the article téen is marked accusative feminine singular (a:f) in agreement with the noun phúsin 'nature'; tóu is genitive masculine singular (g:m) in agreement with its noun prosoópou 'face'. Similarly, in (22) tà (accusative neuter plural) agrees with prágmata 'affairs' and tóon agrees with póleoon 'cities'?

(21) [t-eèn [t-óu prosoóp-ou] phús-in]
the a:f $_{\mathrm{a}}$ the $\mathrm{g}: \mathrm{m}$ face $\mathrm{g}: \mathrm{m}$ 'the nature of the face' P.Pol. $257 \mathrm{~d}^{8}$

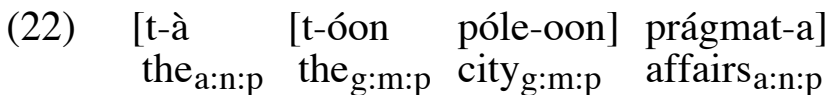
"the affairs of the cities" P.Pol.291c

Adjacent articles such as these result from genitive NPs that are center-embedded in other (in this case accusative) NPs. This is shown in (23), the constituent structure for both (21) and (22).

(23) Center-embedding in noun phrases

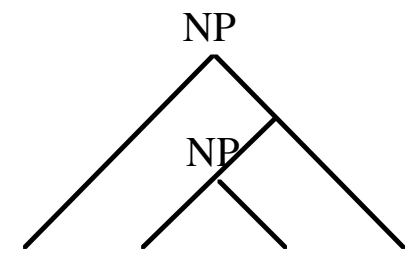

Article Article Noun Noun

Center-embedding in NPs is quite common and occurs with up to three NPs as shown in (24-25) and schematised in (26).

$$
\begin{aligned}
& \text { [t-ò [t-ées [t-óu ksaín-ont-os] tékhn-ees] érg-on] } \\
& \text { the }_{\mathrm{n}: \mathrm{n}} \text { the }_{\mathrm{g}: \mathrm{f}} \text { the } \mathrm{g:m} \text { card-er } \mathrm{g:m} \quad \operatorname{art}_{\mathrm{g}: \mathrm{f}} \quad \text { work }_{\mathrm{n}: \mathrm{n}: \mathrm{p}}
\end{aligned}
$$


'the work of the art of the (wool-)carder' P.Pol.281a

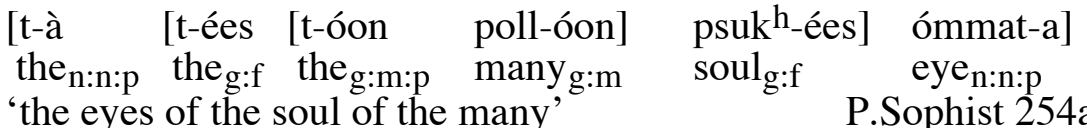

(26) Multiple center-embeddings within noun phrases

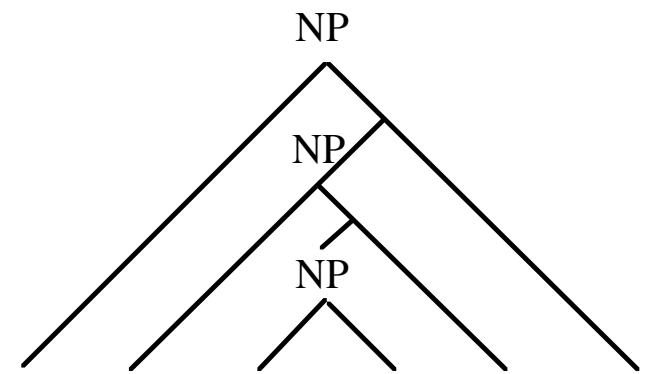

Article Article Article Noun Noun Noun

Center-embeddings like this are systematically unattested when two homophonous articles would be brought together. As Smyth (1920:\$1162) puts it, "the order bringing together the same forms of the article...is avoided, but two or three articles of different form may stand together" (emphasis in original). To empirically substantiate Smyth's observation, I conducted a computer search of all of what remains of Ancient Greek literature.

Greek has four inflectional cases: dative, accusative, nominative and genitive. An NP in any of these cases can take a center-embedded possessor as long as the resulting string does not include adjacent homophonous articles.

The ubiquity of different adjacent articles in possessed NPs may be seen in (27), (29), (31) and (33). Rows in (27) contain the number of occurrences of pairs of articles in which the first is a dative singular (either feminine or masculine/neuter - masculine and neuter are indistinct in the dative singular) and the second is a genitive of some sort; columns indicate the complete corpora of four prose authors. Thus, the first row says that the ordered pair of articles téei 
tées (dative feminine singular, genitive feminine singular) occurs 14 times in the collected works of Aristotle, 4 times in Isocrates, 33 times in Plato and 4 times in Xenophon, for a total of 55 occurrences.

(27) [NP dative [NP genitive]]

$\begin{array}{llrrrrr} & \underline{\mathrm{A}} & \underline{\mathrm{I}} & \underline{\mathrm{P}} & \underline{\mathrm{X}} & \text { Total } \\ \text { d:f g:f } & \text { téei tées } & 14 & 4 & 33 & 4 & \mathbf{5 5} \\ \text { d:f g:mn } & \text { téei tóu } & 64 & 4 & 56 & 10 & \mathbf{1 3 4} \\ \text { d:f gp } & \text { téei tóon } & 2 & 1 & 47 & 16 & \mathbf{6 6} \\ \text { d:mn g:f } & \text { tóoi tées } & 17 & 2 & 21 & 3 & \mathbf{4 3} \\ \text { d:mn g:mn } & \text { tóoi tóu } & 39 & \underline{0} & 45 & 3 & \mathbf{8 7} \\ \text { d:mn gp } & \text { tóoi tóon } & 31 & 4 & 29 & 7 & \mathbf{7 1}\end{array}$

An example of an NP of this sort is given below.

(28) [t-éei [t-ées huphántikees] dunámei]] the $_{\mathrm{d}: \mathrm{f}}$ the $\mathrm{g:f}$ weaving $\mathrm{g:f}$, power $_{\mathrm{d}: \mathrm{f}}$ 'with the power of weaving' P.Pol.281b

Notice that (nearly) all of the cells in (27) are filled. Only one cell here is empty (underlined); this is just the result of the small corpus size for Isocrates, however, as the corresponding cells for the other authors are all filled. The final column in (27) shows that each of the combinations is well attested across different authors.

(29) shows the number of occurrences of pairs of articles in which the first is an accusative singular (masculine and neuter are distinct here) and the second is a genitive of some sort. The pattern here mirrors that of (27): all the cells are filled and the total column is well-populated.

(29) [NP accusative [NP genitive]]

$\begin{array}{llrrrrr} & & \underline{\mathrm{A}} & \underline{I} & \underline{\mathrm{P}} & \underline{X} & \underline{\text { Total }} \\ \text { a:f g:f } & \text { teèn tées } & 119 & 16 & 84 & 11 & \mathbf{2 3 0} \\ \text { a:f g:mn } & \text { teèn tóu } & 270 & 19 & 218 & 29 & \mathbf{5 3 6} \\ \text { a:f gp } & \text { teèn tóon } & 239 & 66 & 304 & 47 & \mathbf{6 5 6} \\ \text { a:m g:f } & \text { tòn tées } & 39 & 4 & 21 & 11 & \mathbf{7 5} \\ \text { a:m g:mn } & \text { tòn tóu } & 2 & 2 & 48 & 9 & \mathbf{6 1} \\ \text { a:m gp } & \text { tòn tóon } & 41 & 11 & 51 & 11 & \mathbf{1 1 4}\end{array}$




$\begin{array}{lllrrrr}\text { a:n g:f } & \text { tò tées } & 136 & 7 & 120 & 3 & \mathbf{2 6 6} \\ \text { a:n g:mn } & \text { tò tóu } & 198 & 1 & 114 & 7 & \mathbf{3 2 0} \\ \text { a:n gp } & \text { tò tóon } & 291 & 11 & 112 & 34 & \mathbf{4 4 8}\end{array}$

An example of such an NP is given in (30).

(30) [t-eèn [t-óon stroomátoon] sún-thesin] the $e_{a: f}$ the $e_{g: f: p}$ bed $d_{g: f: p}$ together-putting $d_{d: f}$ 'the construction of beds' P.Pol.280b

Sequences of articles in which the first is nominative and the second genitive (31) again mirror the patterns shown earlier for datives and accusatives:

(31) [NP nominative [NP genitive]]

$\begin{array}{llrrrrr} & & \underline{\mathrm{A}} & \underline{\mathrm{I}} & \underline{\mathrm{P}} & \underline{\mathrm{X}} & \underline{\text { Total }} \\ \text { n:f g:f } & \text { hee tées } & 106 & 0 & 30 & \mathbf{1 4 0} \\ \text { n:f g:mn } & \text { hee tóu } & 287 & 0 & 79 & 6 & \mathbf{3 7 2} \\ \text { n:f g:p } & \text { hee tóon } & 207 & 4 & 82 & 17 & \mathbf{3 1 0} \\ & & & & & & \\ \text { n:m g:f } & \text { ho tées } & 55 & 1 & 12 & 2 & \mathbf{7 0} \\ \text { n:m g:mn } & \text { ho tóu } & 75 & 1 & 34 & 10 & \mathbf{1 2 0} \\ \text { n:m g:p } & \text { ho tóon } & 41 & 3 & 20 & 12 & \mathbf{7 6} \\ & & & & & & \\ \text { n:n g:f } & \text { tò tées } & 137 & 7 & 119 & 3 & \mathbf{2 6 6} \\ \text { n:n g:mn } & \text { tò tóu } & 196 & 1 & 114 & 7 & \mathbf{3 1 8} \\ \text { n:n g:p } & \text { tò tóon } & 290 & 11 & 112 & 34 & \mathbf{4 4 7}\end{array}$

(Again, the zeros in Isocrates are due to the small size of his collected works.) An example of this sort of NP is given in (32).

(32) [h-ee [t-óu pleéth-ous] arkh-eé] the $_{\mathrm{n}: \mathrm{f}}$ the $_{\mathrm{g}: \mathrm{n}}$ crowd $_{\mathrm{g}: \mathrm{n}}$ rule $_{\mathrm{d}: \mathrm{f}}$ 'the rule of the crowd (democracy)'

P.Pol.291d

But compare (27), (29) and (31) to (33), which shows the number of occurrences of pairs of articles in which both are genitive.

(33) [NP genitive [NP genitive]]

$\underline{A} \quad \underline{I} \quad \underline{P} \quad \underline{X} \quad \underline{\text { Total }}$




\begin{tabular}{|llrrrrr|}
\hline g:f g:f & tées tées & 0 & 0 & 0 & 0 & $\mathbf{0}$ \\
\hline g:f g:mn & tées tóu & 130 & 6 & 71 & 8 & $\mathbf{2 1 5}$ \\
g:f g:p & tées tóon & 97 & 44 & 74 & 19 & $\mathbf{2 3 4}$
\end{tabular}

\begin{tabular}{llrrrrr|}
\hline g:mn g:mn & tóu tóu & 0 & 0 & 0 & 0 & $\mathbf{0}$ \\
\hline g:mn g:f & tóu tées & 11 & 0 & 10 & 3 & $\mathbf{2 4}$ \\
g:mn p & tóu tóon & 13 & 4 & 8 & 5 & $\mathbf{3 0}$
\end{tabular}

\begin{tabular}{llrrrrr|}
\hline g:p g:p & tóon tóon & 0 & 0 & 0 & 0 & $\mathbf{0}$ \\
\hline g:p g:f & tóon tées & 33 & 8 & 28 & 9 & $\mathbf{7 8}$ \\
g:p g:mn & tóon tóu & 45 & 4 & 35 & 8 & $\mathbf{9 2}$
\end{tabular}

An example of this kind of NP is given in (34).

$$
\begin{array}{lll}
\text { [t-ées [t-óon himatí-oon] } & \text { ergasí-as] } \\
\text { the } \text { g:f }_{\text {th:n:p }} \text { clothing: } \text { th:p }_{\mathrm{g}}, \text { production }_{\mathrm{d}: \mathrm{f}} & \\
\text { 'of the production of clothing' } & \text { P.Pol.280e }
\end{array}
$$

In (27), (29) and (31) none of the pairs of articles is homophonous and (almost) every cell is filled. In (33), on the other hand, a number of cells (those in the rectangular boxes) contain homophonous pairs of articles and exactly these cells are empty. ${ }^{9}$

Expanding the search to cover all of attested Greek literature from Homer (mid-8th century BCE) to Chares (3rd to 2nd century BCE) yields not a single pair of adjacent homophonous articles:

(35) Greek literature to the 3rd century BCE $\begin{array}{cccc} & \text { tóu tóu } & \text { tées tées } & \text { tóon tóon } \\ \text { all authors } & 0 & 0 & 0\end{array}$

This search spans 500 years and 67 authors and includes genres from comic and tragic plays to biography, philosophy, history, poetry, and oration in a number of Greek dialects including Aeolic, Attic, Doric, and Ionic. This confirms that the generalization is not merely a trend, nor is it limited by dialect, genre or period. ${ }^{10}$

So far I have shown that there is an asymmetry in the attested types of centerembedded noun phrases in Greek such that NPs with adjacent homophonous 
articles are systematically unattested. This is not to say, however, that nonadjacent homophonous articles are not allowed. Identical forms of articles often appear within a possessed NP, but never adjacently. The internal syntax of noun phrases in Greek allows an alternative to center-embedding of a possessive NP: one commonly finds genitival NPs postposed (36) rather than center-embedded (37).

$$
\begin{aligned}
& \text { [[h-ee tólm-a] [t-óon leg-ónt-oon]] } \\
& \text { the }_{n: f} \text { courage }_{n: f} \quad \text { the }_{g: m: p} \text { speak-ing } g: m: p \\
& \text { 'the courage of those speaking' } \\
& \text { [h-ee [t-óon leg-ónt-oon] tólm-a] } \\
& \text { the }_{n: f} \text { the }_{\mathrm{g}: \mathrm{m}: \mathrm{p} \text { speak-ing }} \text { :m:p }, \quad \text { courage }_{\mathrm{n}: \mathrm{f}} \\
& \text { 'the courage of those speaking' }
\end{aligned}
$$

[construct]

Such postposed genitives are always available for cases in which centerembedding would result in adjacent homophones (38).

$$
\begin{aligned}
& \text { [[[t-óon oikeí-oon] tin-às] [t-óon ekeín-oon]] } \\
& \text { the }_{\mathrm{g}: f: p} \text { slave }_{\mathrm{g}: f: p} \quad \text { some }_{\mathrm{f}: \mathrm{a}: \mathrm{p}} \text { the } \mathrm{g:m:p} \text { those }_{\mathrm{g}: \mathrm{m}: \mathrm{p}} \\
& \text { 'some of the slaves of those [people]' }
\end{aligned}
$$

Were (38) to be center-embedded, it would contain adjacent homophones, as the ungrammatical construct in (39) shows.

$$
\begin{aligned}
& \text { * [[t-óon [t-óon ekeín-oon] oikeí-oon] tin-às] } \\
& \text { the }_{g: f: p} \text { the }{ }_{g: m: p} \text { those } e_{\text {:f:p }} \text { slaves } g: m: p \text { somef:a:p } \\
& \text { 'some of the slaves of those [people]' [construct] }
\end{aligned}
$$

Cases like (38) abound while cases like (39) are unnattested. For instance, cases of two non-adjacent feminine genitive singular articles are common enough $(40,42)$, although adjacent instances of homophonous articles do not occur (41, 43) as has been seen.

$$
\begin{aligned}
& \text { [[t-ées arkh-ées] [t-ées pól-eoos]] } \\
& \text { the } \text { g:f dominion }_{\mathrm{g}: \mathrm{f}} \text { the } \mathrm{g}_{\mathrm{f}} \mathrm{f} \text { city } \mathrm{g}: \mathrm{f} \\
& \text { 'of the dominion of the city' }
\end{aligned}
$$

P.Pol 275a 8 


$$
\begin{aligned}
& \text { *[[t-ées [t-ées pól-eoos] arkh-ées }]] \\
& \text { the }{ }_{\mathrm{g}: \mathrm{f}} \text { the } \mathrm{g}_{\mathrm{g}: \mathrm{f}} \text { city } \mathrm{g}: \mathrm{f} \text { dominion } \mathrm{g}: \mathrm{f} \\
& \text { 'of the dominion of the city' }
\end{aligned}
$$

[apò [[t-ées arkh-ées] [t-ées metabás-eoos]]] from the $e_{\mathrm{g}: \mathrm{f}}$ beginning $\mathrm{g}: \mathrm{f}$ the $\mathrm{g:f}$ change $\mathrm{g}: \mathrm{f}$

'from the beginning of the change' A.Poet 2.1455b 28

$$
\begin{aligned}
& \text { *[apò [t-ées [t-ées metabás-eoos] arkh-ées]]] } \\
& \text { from the } \text { g:f }_{\mathrm{f}} \text { the } \text { g:f }_{\mathrm{f}} \text { change } \mathrm{g}: \mathrm{f} \text { beginning } \mathrm{g}: \mathrm{f} \\
& \text { 'from the beginning of the change' [construct] }
\end{aligned}
$$

Cases like these show that only adjacent homophones are ruled out.

Why should adjacent definite articles be prohibited just in case they are homophonous? I would like to propose that this is motivated by the Obligatory Contour Principle (OCP). The OCP prohibits consecutive identical autosegments (Leben 1973, 1978; Goldsmith 1976, 1984; Pulleyblank 1986), segments (Steriade 1982; Schein \& Steriade 1986; Hayes 1986; Prince 1984) or syllables (Yip 1993). It is generally taken to constrain the application of rules as well as the shapes of underlying morphological representations (McCarthy 1988; Clements 1988; Davis 1991).

McCarthy (1986) coined the term 'antigemination' for a constraint which prohibits syncope rules from creating clusters of identical consonants. McCarthy attributes the blocking affect to the OCP: a derivation that yields a violation of the OCP is blocked. The phenomenon is widespread (Borowsky 1987; Archangeli 1986; Clark 1986; Itô \& Mester 1986; Myers 1987; Yip 1988). Returning now to the Greek data, we may introduce the term antihomophony for the blocking of a syntactic construction that would contain a violation of the OCP at the phonological word level of representation: antihomophony bans adjacent 
homophonous morphemes within a phonological word. Using ( $\square$ ) to indicate some stretch of sound, A and B to indicate some stretch of meaning, and $\square$ to indicate a phonological word, we may formulate antihomophony as follows:

(44) Antihomophony

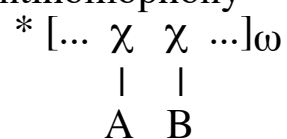

Note that antihomophony is not a restriction against adjacent identical syllables, which may occur across word-boundaries (45) and within wordboundaries as a result of affixation (46) or reduplication (47):

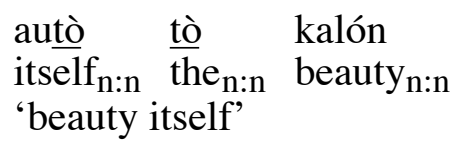

$$
\begin{aligned}
& \text { toút-ou [toú.tou] 'this } \mathrm{g}_{\mathrm{g}: \mathrm{mn}} \text { ' } \\
& \text { luu-s-aás-aa [luu.saá.saa] 'loose }{ }_{a} \text { or fual part' } \\
& \text { (47) ke-kéleu-ka [ke.ké.leu.ka] 'redupcommand } 1 \mathrm{spf} \\
& \text { dé-de-ka [dé.de.ka] 'redupbind } 1 \mathrm{spf}
\end{aligned}
$$

Rather, it is a constraint against adjacent homophones. This is clearly brought out in the contrast between [toútou [tóu érgou]] 'of this work' (48) and [tóu [tóu érgou]...] (49).

$$
\begin{aligned}
& \begin{array}{lll}
\text { toútou tóu } & \text { érgou } \\
\text { this }_{\mathrm{g}: \mathrm{n}} & \text { the }_{\mathrm{g}: \mathrm{n}} & \text { work }_{\mathrm{g}: \mathrm{n}}
\end{array} \\
& \text { (49) * tóu tóu érgou } \\
& \text { the }_{\mathrm{g}: \mathrm{n}} \quad \text { the }_{\mathrm{g}: \mathrm{n}} \quad \mathrm{job}_{\mathrm{g}: \mathrm{n}}
\end{aligned}
$$

(48) has no adjacent homophones and thus does not violate the OCP; (49) does have adjacent homophones (tou and tou) and is ruled out. Whereas the structure in (48) occurs quite commonly in Greek, the one in (49) is unattested:

$$
\begin{array}{rrrrrr} 
& \mathrm{A} & \mathrm{I} & \mathrm{P} & \mathrm{X} & \text { Total } \\
\text { toútou tóu } & 52 & 2 & 70 & 23 & \mathbf{1 4 7}
\end{array}
$$


tóu tóu

0

0

0

0

0

Of course, not any two homophonous words are subject to antihomophony. Paul Kiparsky (p.c.) points out that the restriction against homophones does not apply to sequences of content words. Consider the adjacent homophonous content words in (51) and (52), both from Plato's Symposium.

(51) ho éroo-s éroo-s estìn ouden-òs eè tin-ós; the $_{\mathrm{m}}$ Desire $_{\mathrm{m}}$ desire $_{\mathrm{m}}$ is nothing $\mathrm{g}: \mathrm{n}$ or some-thing $\mathrm{g}: \mathrm{n}$ 'Is Desire desire of nothing or of something?' P.Symp.199e6

(52) hóti éstin hué-os gè thugatr-òs hopateèr pateér that is son $\mathrm{g:m}$ PRT daughter $\mathrm{g}: \mathrm{f}$ the father father 'that a father is the father of a son or a daughter, right?' ibid.199d6

What allows (51) and (52) to slip through the ban on adjacent homophones is that the homophony occurs across rather than within phonological words.

One might well suppose that it is not the phonological identity of adjacent definite articles that is prohibited but the identity of the morpho-syntactic features (case, gender, number) that define them. Thus, it might be argued, the sequence tées tées is not phonologically ill-fomed but morpho-syntactically ill-formed because the full set of features that identifies each morpheme is repeated: [gen fem sg] [gen fem sg]. The prohibition in question could then be given as in (53), where $\square \mathrm{F}, \square \mathrm{G}, \square \mathrm{H}$ are the feature-value pairs that define the morphemes in question.

(53) $*[\square \mathrm{F} \square \mathrm{G} \square \mathrm{H}][\square \mathrm{F} \square \mathrm{G} \square \mathrm{H}]$

The prohibition is ad hoc but does make the correct prediction for the case at hand, *[gen fem sg] [gen fem sg]. But consider now the full set of articles in Greek. 


\begin{tabular}{lllllllll} 
& \multicolumn{9}{c}{ Singular } & & \multicolumn{3}{c}{ Plural } \\
$\underline{\text { fem }}$ & hee & Gen & Dat & Acc & Nom & Gen & Dat & Acc \\
$\underline{\text { masc }}$ & ho & tóei & teén & hai & tóon & táis & taás \\
$\underline{\text { neut }}$ tó & tóu & tóoi & tón & hoi & tóon tóis & toús \\
& & & & & tá & tóon tóis tá
\end{tabular}

Although the prohibited *tées tées consists of two identical morpho-syntactic feature matrices, only some of the cases of prohibited *tóu tóu and *tóon tóon are featurally identical. This is because the phonological shape tóu may be either [gen masc sg] or [gen neu sg]; and the phonological shape tóon may be [gen fem $\mathrm{pl}$ ], [gen masc pl] or [gen neu pl]. So although (53) would rule out all cases of *tées tées, it would rule out only some of the *tóu tóu cases (the cases in which both articles are either masculine or neuter) and only some of the *tóon tóon cases (the case in which both articles are either feminine, or masculine or neuter) as shown below.

(55) Morpho-syntactically identical (=) vs. unattestested (*) pairs

\begin{tabular}{|c|c|c|c|c|}
\hline tées tées & $=$ & * & [gen fem sg] & [gen fem sg] \\
\hline \multirow{4}{*}{ tóu tóu } & $=$ & * & [gen masc sg] & [gen masc sg] \\
\hline & & * & [gen masc sg] & [gen neu sg] \\
\hline & $=$ & * & [gen neu sg] & [gen neu sg] \\
\hline & & * & [gen neu sg] & [gen masc sg] \\
\hline \multirow[t]{9}{*}{ tóon tóon } & $=$ & * & [gen fem pl] & [gen fem pl] \\
\hline & & * & [gen masc pl] & [gen fem pl] \\
\hline & & * & [gen neu pl] & [gen fem pl] \\
\hline & & $*$ & [gen fem pl] & [gen masc pl] \\
\hline & $=$ & $*$ & [gen masc pl] & [gen masc pl] \\
\hline & & $*$ & [gen neu pl] & [gen masc pl] \\
\hline & & * & [gen fem pl] & [gen neu pl] \\
\hline & & $*$ & [gen masc pl] & [gen neu pl] \\
\hline & $=$ & $*$ & [gen neu pl] & [gen neu pl] \\
\hline
\end{tabular}

But the phonological sequences *tóu tóu and * tóon tóon are prohibited regardless of their morpho-syntactic featural composition. Thus an analysis in terms of morpho-syntactic features is unable to capture the classes of non-occurring pairs of articles. ${ }^{11}$ 
It might be possible to devise an underspecified morpho-syntactic representation in which phonologically identical articles are always featurally identical. The genitive masculine and neuter singular tóu might then be simply [gen, -fem, -pl]. One would then need to locate some principle of grammar (analogous to the OCP) that forbade such a sequence; I am aware of no such principle in the literature. In any case, a morphosyntactic analysis cannot work with the morphological cases of antihomophony in Greek (section 3), in Japanese or in Italian (section 4) because the items that violate antihomophony in each of these cases are indisputably morphosyntactically distinct. I turn now to the first of these cases.

\section{Antihomophony and morphology}

Antihomophony holds both within lexical phonological words and within postlexical phonological words or clitic groups. ${ }^{12}$ We've already considered what happens when a syntactic construction (a center-embedded NP) violates it: the construction is blocked and another equivalent syntactic structure (NP with a postposed possessor) takes its place. We turn now to the effects of antihomophony on morphology. Here there are two cases, one involving morphological haplology (2.1), the other involving allomorphy of a negative particle (2.2).

3.1 Reduplicative e- and past tense e- 
The first case is discussed by Stemberger (1981) as an instance of morphological haplology. Consider the reduplicated perfect and pluperfect stems graph 'write' and phthi 'decline':

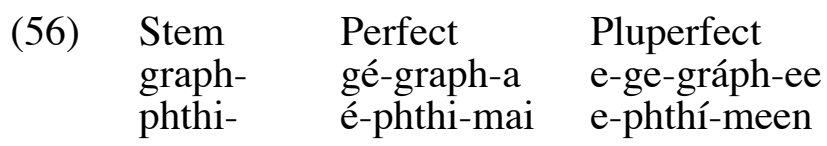

Roots like graph-, which reduplicate the initial consonant with a fixed vowel [e], take the past tense prefix e- in the Pluperfect. But stems like phthi-, whose reduplicant consists solely of $\underline{\mathrm{e}}-{ }^{13}$ fail to take the past tense marker $\underline{\mathrm{e}}-$ in the Pluperfect. Stemberger points out that morphological haplology is obligatory before a morpheme e- and never occurs with a non-morphemic stem-intial /e/. That is, only heteromorphemic e's that are themselves morphemes delete, in conformity with (44). The deletion can be understood as a response to the ranking of prosodic constraints over morphological constraints in Greek:

\begin{tabular}{||r|c|c||}
\hline & PHON & MORPH \\
\hline e-e-phthí-meen & $* !$ & \\
\hline \hline$<$ e->e-phthí- & & $*$ \\
meen & & \\
\hline
\end{tabular}

The phonological constraint in question is antihomophony and the morphological constraint is EXPONENCE (Prince \& Smolensky 1993), a constraint which requires that morphemes be overt. Antihomophony forces violation of the latter constraint, suggesting that this phonological constraint outranks a morphological constraint. 


\section{2 meé, meé and ou}

Other data from Greek show antihomophony at work in a startling way: in these data, antihomophony forces the appearance of a contextually inappropriate allomorph of a negative particle. In this case, phonology does not pick between competing structures as it does with center-embedded and postposed NPs; instead, it forces a violation in the morphology, yielding a realis negative in an irrealis context.

The data concerns the homophones meé 'not' and meé 'lest'. The first is a negative particle that occurs in irrealis clauses, the second a complementizer that governs irrealis clauses. The fact to be explained is that mee 'not' is replaced with the realis negative ou 'not' in irrealis clauses just in those cases where the clause is governed by meé 'that'. I argue that this is another instance of antihomophony. ${ }^{14}$

meé is used in irrealis contexts primarily governing optative (58), subjunctive (59) and imperative (60) verb forms.

(58) eè meé dzoó-ieen

or not live 1 opt

'or may I not live'

Ar. Eq. 833

(59) meè phóo-men

not say1p subj

'shall we not say?'

P. Rep.554b

(60) meè még-a lég-e

not biga:n:p speak 2 imp 'don't boast'

P. Ph.95b

The other negative particle, ou (ouk before a vowel-initial word) is used in realis contexts primarily governing indicative forms of the verb (61).

(61) ouk en-no-óo 
not in-mind 1 ind

'I don't recall' $\quad$ P. Euth1b 12

The string meé also occurs as a subordinating conjunction ('lest') introducing subordinate clauses like the object clauses used with verbs of fearing (62-63).

(62) dé-doi-ka meè... epilathoó-metha t-ées oík-ade hod-óu redupfear 1 pf lest lose 1 p subj the $\mathrm{g:f}$ homeward $\operatorname{road}_{\mathrm{g}: \mathrm{f}}$ 'I fear we may forget the way home' X. A.3.2.25

(63) édei-s-an h-oi hélleen-es meè pros-ág-oien fear3 $\mathrm{p}$ aor the $\mathrm{n:m:p}$ Greek $\mathrm{n:m:p}$ lest forth-lead 3 p opt 'The Greeks feared they might advance...' X. A.1.10.9

Depending on the tense/aspect of the matrix verb, the verbs of these subordinate clauses are marked for either subjunctive (62) or optative (63) mood. Recall now that the normal negative for subjunctives and optatives is (irrealis) meé rather than (realis) ou. When (62) and (63) are negativised with meé, we expect to find two adjacent instances of meé ('lest' and 'not'); in precisely these cases, the second meé is replaced by ou, despite the fact that the clause in which the negative occurs is irrealis. Consider the negative object clause in (64), comparing it to the nonnegative object clauses in (62-63).

$$
\begin{array}{lll}
\text { dé-di-men } & \text { meè ou bébai-oi } & \text { ée-te } \\
\text { redupfear } 1 \text { p indic lest not } & \text { steadyn:m:p } & \text { be } 2 \text { p subj } \\
\text { 'We fear you are not to be depended on' } & \text { T. } 3.57
\end{array}
$$

In (64) the verb of the subordinate clause (éete 'you are') appears in the subjunctive, but the negative that goes with it is (realis) ou rather than the expected (irrealis) meé. The conditioning factor is the preceding meé 'lest'. The prosodic constituency of (64) is given in (65): meé, ou and éete 'be' are all function words and do not form phonological words of their own. Note that 
replacing realis ou with (the contextually appropriate) irrealis meé would result in adjacent homophones internal to a phonological word (66).

(65) contextually inappropriate negative: grammatical

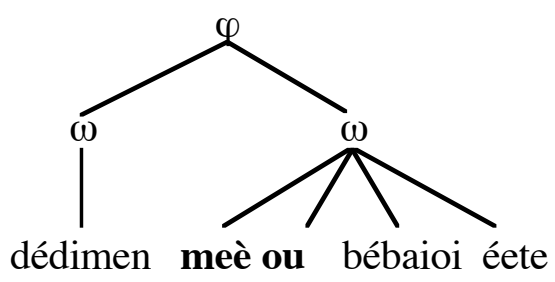

(66) contextually appropriate negative: ungrammatical

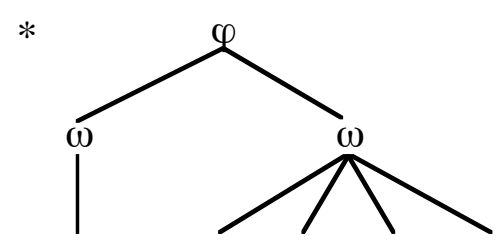

dédimen meè meè bébaioi éete

A computer search reveals that adjacent instances of heteromorphemic meé are completely unattested in the Greek corpus. ${ }^{15}$

That the conditioning factor is meé can also be seen in negative clauses introduced by conjunctions other than meé, in which irrealis negative meé surfaces with subjunctive and optative verbs as expected. Compare irrealis meé in (67) and (68) with contextually inappropriate realis ou in (60).

$$
\begin{aligned}
& \text { hína meè t-à } \quad \text { zdeúg-ee heem-óon } \\
& \text { so that not theeg-éei } \\
& \text { 'so that our wagons not command us }
\end{aligned}
$$

(68) hópoos meè apothán-eei so that not $\operatorname{die}_{3}$ sg subj 'so that he will not die'

X.M.2.10.2

The unexpected occurrence of the realis negative particle ou in irrealis contexts in which the negative particle follows meé 'lest' is another clear case of 
antihomophony. The prohibition against adjacent homophonous function words captures a significant generalization between two otherwise puzzling facts: (i) adjacent homophonous articles are systematically avoided and (ii) the realis particle ou is used in irrealis contexts only when it occurs in a clause headed by the complementiser meé.

The important difference between these two cases lies in the nature of the structures that antihomophony chooses from. The tableaux in (69-70) summarize the analysis. Consider first the center-embedded NP case (69). The first candidate violates antihomophony; the third violates a morphological constraint on agreement (tóu is masculine or neuter, póleoos is feminine); the second violates neither and is the only grammatical candidate.

(69)

\begin{tabular}{|r|c|c|c||}
\hline & SYN & PHON & MORPH \\
\hline (tées tées póleoos) (arkhées) & & $* !$ & \\
\hline$\square$ (tées arkhées) (tées póleoos) & & & \\
\hline (tées tóu póleoos) (arkhées) & & & $* !$ \\
\hline
\end{tabular}

In the meè meé case (70) antihomophony chooses between a contextually appropriate form (irrealis meé) and a contextually inappropriate form (realis $\underline{\text { ou}}$ ) and forces the appearance of the latter.

(70)

\begin{tabular}{||r|c|c|c||}
\hline & SYN & PHON & MORPH \\
\hline (meè meé bébaioi éete) & & $* !$ & \\
\hline$\square \quad$ (meè ou bébaioi éete) & & & $*$ \\
\hline
\end{tabular}


This shows that antihomophony is ranked higher than the constraint that selects appropriate allomorphs for various morpho-syntactic environments.

\section{Other cases}

The argument presented above rests on the claim that prosodic constraints never force syntactic ill-formedness (but may force morphological ill-formedness). In this section I review all the cases I know of that bear on this issue and conclude that they are consistent with this claim.

\subsection{Antihomophony}

I'm aware of two additional cases of antihomophony in the literature. Both show the same thing: when the syntax threatens a violation of antihomophony, the morphology, never syntax, is the component that yields.

\subsubsection{Japanese}

Japanese has three syntactic particles - genitive, nominal, copula - with the same phonological shape [no]. As Poser (1984) has shown, however, the language does not generally tolerate adjacent occurrences of no. Where we would expect two instances of no we find only one:

(71) Japanese *no no

a. no (genitive) + no (nominal )

$$
\begin{aligned}
& \text { *Zyon no no } \\
& \text { John GEN NOM } \\
& \text { 'John's (thing)' } \\
& \text { Zyon no } \\
& \text { 'John's (thing) }
\end{aligned}
$$


b. no (copula) + no (nominal $)$

*utyooteN no no wa Hanako da
ecstatic COP NOM TOP Hanako be
utyooteN na no wa Hanako da
'The one who is ecstatic is Hanako.'

Poser proposes the following deletion rule for Japanese ${ }^{16}$ :

(72) No-Haplology: no $>\varnothing / \ldots$ no

The alignment constraints governing prosodic phrasing in Japanese are given in (73), following Terada (1986), Selkirk (1990) and others.

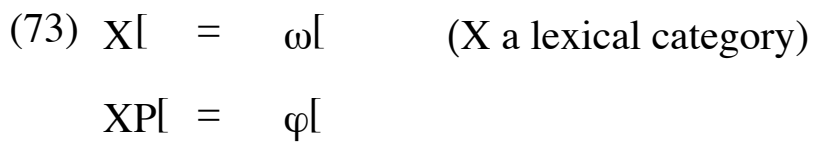

This yields the following prosodic constituencies for the phrases in (71):

(74) Prosodic Phrasing
a. (Zyon no no) $\square$
b. (utyooteN no no wa) $\square$ (Hanako da) $\square(71 b)$

The haplology in (71) can thus be attributed to antihomophony, exactly as in Greek. The different outcomes in the two languages are attributable to the syntax: Japanese has no syntactic alternatives to the no no cases but Greek does have syntactic alternatives to the tées tées, etc. cases, namely postposition of the embedded NP. A tableau for (71b) is given below, in which $<$ no $>$ marks the occurrence of an EXPONENCE violation.

\begin{tabular}{||r|c|c|c||}
\hline & SYN & PHON & MORPH \\
\hline (utyooteN no no wa) (Hanako da) & & $* !$ & \\
\hline$\square \quad$ (utyooteN no <no> wa) (Hanako da) & & & $*$ \\
\hline
\end{tabular}




\subsubsection{Italian}

The second case of antihomophony outside of Greek comes from Italian. The syntax of Italian should produce a number of homophonous clitic sequences, but these are not allowed. Instead, one finds substitutions of other clitics for one of the offending homophones (Lepschy \& Lepschy 1989, 212; Bonet 1991). The expected sequence si si (reflexive + impersonal) in (76) surfaces instead as ci si.

(76) *quando si si sgevlia presto, si si alza volentieri when refl imp wake early refl imp rise willingly quando ci si sgevlia presto, ci si alza volentieri 'when one wakes up early, one gets up willingly'

Here again, the syntax offers no other order of clitics, so antihomophony is not selecting among two or more equal syntactic candidates. Rather, antihomophony forces the mis-selection of a morphological exponent for the reflexive: reflexive

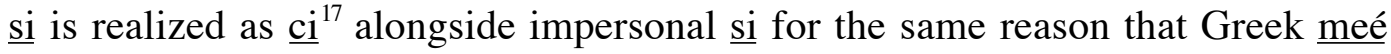
'not' is realized as ou alongside meé 'lest' - avoidance of homophones within a phonological word ${ }^{18}$ is more important than exact morphological identity:

\begin{tabular}{|r|c|c|c||}
\hline & SYN & PHON & MORPH \\
\hline (si si alza) (volentieri) & & $* !$ & \\
\hline$\square \quad$ (ci si alza) (volentieri) & & & $*$ \\
\hline
\end{tabular}

\subsection{Heaviness}

Two additional cases of prosodic influence on syntax need to be examined here. Both have been recently discussed in Zec \& Inkelas (1990). 


\subsubsection{English}

The first involves heavy NP shift in English:

(78) a. He threw into the wastebasket the letter which he had not decoded

b. * He threw into the wastebasket the letter

c. * He threw into the wastebasket it

$(78 \mathrm{~b}, \mathrm{c})$ are ungrammatical according to Zec and Inkelas because the postposed NPs the letter and it are not prosodically heavy, i.e., do not contain branching phonological phrases. But both postposed and in situ constuctions are available in English, as (79) shows:

(79) a. He threw the letter which he had not decoded into the wastebasket

b. He threw the letter into the wastebasket

c. He threw it into the wastebasket

The prosodic constraint here rules out one of two available syntactic structures, exactly as in the Greek data discussed in section 2:

\begin{tabular}{||r|c|c|c||}
\hline & SYN & PHON & MORPH \\
\hline \hline$\quad$ (he threw it) (into the wastebasket) & & & \\
\hline (he threw) (into the wastebasket) (it) & & $* !$ & \\
\hline
\end{tabular}

\subsubsection{Serbo-Croatian}

Zec and Inkelas' second case involves topicalization in Serbo-Croatian: a topicalised constituent must consist of a branching phonological phrase. Again, the heaviness constraint does not place any direct conditions on syntactic 
constructions - it merely chooses between two already available constructions, one with a preposed topic, the other with the topic in situ.

\section{Alternative accounts}

In the preceding sections I've tried to show that the only effect prosody ever has on syntax is to choose between structures which are equally well-formed syntactically. The constraint-based analysis in (3) predicts exactly this because it is couched within a theory of grammar (OT) whose only role for dominated constraints is to select among representations which are not ranked by higher ranked constraints. (3) does not allow prosody to block a syntactic construction if it is the only syntactic construction available: the very nature of Optimality Theory guarantees an output, even if that output violates a constraint.

On the other hand, syntactic influence on prosody is almost total: the phrasing algorithms for phonological words and phrases are strictly determined by (but not reducible to) syntactic bracketing and labeling. Again, (3) has this as a natural result: alignment of prosodic and syntactic categories brings prosodic constituency in line with syntactic constituency, not the reverse.

How might the models based on the premises in (1) and (2) account for this? Let's begin with the first type, repeated below as (81):

(81) Syntax derivationally precedes phonology (81) is subject to both a weak and a strong interpretation. Myers (1991) offers the strong interpretation, claiming that constraints on phonological representations can block only phonological rules. If the antihomophony analysis of the Greek facts above is correct, this must be wrong. 
A weaker interpretation of (81) would include constraints that can in principle filter out unwanted syntactic structures. Such a model would allow a prosodic constraint like antihomophony to filter out the offending cases. The problem in this case is that such filters are clearly too strong. (81) can handle the centerembedding facts by generating both center-embedded and post-posed possessives and filtering out offending cases with antihomophony. Given such an analysis, however, (81) becomes too weak to rule out another possiblity. Imagine a language Greek $\square$ such that the syntax only produces center-embedded possessors; a grammar with rules and filters has no principled way of keeping antihomophony from blocking these structures too, with the result that there would be no grammatical way to express a possessed NP with homophonous articles. The attested Greek facts do not warrant such a strong role for filters.

Similarly for the English and Serbo-Croatian cases: each shows a prosodic constraint that rules out one of two competing syntactic expressions. There are no cases wherea prosodic constraint rules out the only available syntactic expression. Such cases are easily imaginable: eg, a dialect of German in which the strings die die and das das are ungrammatical or a dialect of Italian in which 'one gets up willingly' is not expressible.

Now let us consider Zec and Inkelas's (1990) bidirectional model (2), repeated below as (82):

(82) Syntax constrains prosody and vice versa

Such a model has no difficulty with the Greek data presented here, of course. The problem is that (82) predicts the existence of grammars in which prosody plays a role in determining syntactic well-formedness: in particular, (82) is 
compatible with a grammar in which prosodic structure and labeling dictate syntactic structure and labeling. So in addition to cases like (83a), where the constituency and labeling $\left(\mathrm{XP}, \mathrm{X}^{0}\right)$ of the syntax determine the prosodic structure, we should have cases like (83b) where the constituency and labeling $(\square, \mathrm{P})$ determine the syntactic structure.
a. $\mathrm{S}$ determines $\mathrm{P}$
b. $\mathrm{P}$ determines $\mathrm{S}$

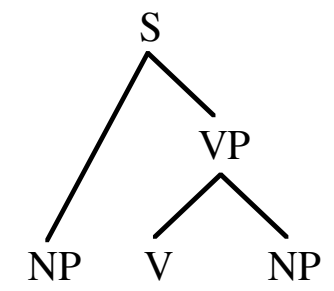

Pat planted celery

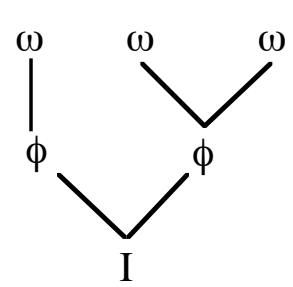

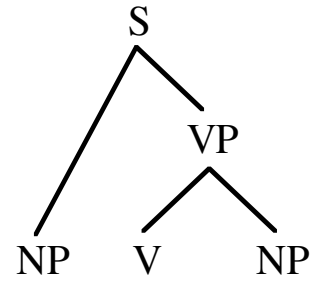

Pat planted celery

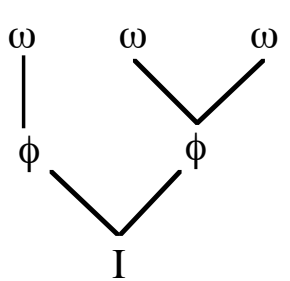

(83b) allows constraints on the syntax of the following type:

(83) Possible constraints in a bidirectional model

(i) any branching phonological phrase constitutes a verb phrase

(ii) any non-branching phonological phrase constitutes a noun phrase

But such prosodic constraints on syntactic constituency and labeling do not occur in natural language. This shows that the Zec and Inkelas model is too permissive, as it has no principled way of excluding constraints of this type. 


\section{Conclusion}

All the data of which I'm aware suggest that prosodic constraints play a very limited, but nonetheless important role in filtering out possible syntactic representations. Essentially, prosody can block syntactic constructions only if there are other structures that can fill in for the blocked ones. This special type of blocking scenario is predicted by the model presented in (3). Derivational models (1) and models in which prosody interacts with syntax bidirectionally (2) are unable to capture this directly. 
Notes

* This work would not have been possible without extensive free use of the computerized corpus Thesaurus Linguae Graecae. I would like to thank D. J. Mastronarde for helping me get access to this incredible source of data. I would also like to thank Cheryl Chan, Stan Hoffer, Sharon Inkelas, Michael Israel, Paul Kiparsky, Geoff Pullum, John Rickford, Ivan Sag, Tom Wasow, Richard Wiese and Moira Yip for helpful input. A large debt of gratitude to two anonymous NLLT reviewers, two anonymous Phonology reviewers and to Ellen Kaisse, whose careful comments and suggestions were invaluable. All errors or inconsistencies are of course my own.

1 Zec and Inkelas (1990) assume that all syntax-phonology interactions are mediated by prosodic structure. This allows prosody some interaction with syntax but denies it to segmental and sub-segmental phonological information. Thus the term 'prosody' rather than 'phonology' in (2).

2 The constraint seems to generalize to any string of homophonous function words, at least for some speakers. In my speech, for instance, phrases like * the star in In Harm's Way, *he went to To Live and Die in L.A., * the video of Of Thee I Sing are ungrammatical without a pause between the offending homophones.

3 The second and third homophones may be separated by an adverb:

(a) die die gestern die Blumen gekauft haben those who yesterday the flowers bought have 'those who bought the flowers yesterday'

(b) das das wirklich das Problem ist that this really the problem is 'that this really is the problem' 
4 Hayes 1989 was circulated in 1984 as a manuscript; hence the funny chronology of the citations.

5 Tonally dependent words are best analyzed as bearing floating high tones (Sauzet 1989, Golston 1989). There is no segmental, metrical or epigraphic evidence for a prosodic constituent E-Word, as argued for in Steriade 1988.

6 I use NP as a theory-neutral cover term for DP, N", etc.

7 Glosses are marked for case, gender and number in that order, using the following abbreviations:

$$
\begin{array}{ll}
\mathrm{a}=\text { accusative } & \mathrm{g}=\text { genitive } \\
\mathrm{f}=\text { feminine } & \mathrm{d}=\text { dative } \\
\mathrm{p}=\text { plural } &
\end{array}
$$

Nominative case and singular number are left unmarked in the glosses.

8 The following abbreviations are used for authors and their works.
A Aristotle
Poet
Ars Poetica
M
Metaphysics

Ar Aristophanes

$\mathrm{Eq}$

Equites

I Isocrates

L Lysias

P Plato
A
Euth
$\mathrm{Ph}$
Apology
Euthyphro
Pol
Phaedo
Rep Republic
$\mathrm{S}$
Politicus ('Statesman')
Symp
Sophist
S Sophocles
Symposium
OC
Oedipus at Colonus
$\mathrm{T}$ Thucydides
Peloponnesion Wars

$\mathrm{X}$ Xenophon

A
Oec

Anabasis

Memorabilia

Oeconomicus

9 The corpus contains one possible exception, from Aristotle's Metaphysics: 


t-óu t-óu ónt-os t-ò mèn tó-de éinai
the g:n the $_{\mathrm{g}: \mathrm{n}}$ being $\mathrm{g}$ :n the ${ }_{\mathrm{a}: \mathrm{n}}$ PRT this be inf
'of the (property) of the being of being this'

In Aristotle's time, tone and word-division were not marked. What is written here as tóu tóu was merely TOUTOU; this means that it could also be read as the genitive singular deictic toútou 'this':

toút-ou ónt-os t-ò mèn tó-de éinai
this $\mathrm{g}_{\mathrm{g}} \mathrm{n}$ being $\mathrm{g}: \mathrm{n}$ the $\mathrm{a}: \mathrm{n}$ PRT this be
'of this being of being this

The text is found in 4 medieval manuscripts, all of which indicate both tone and word-division: two manuscripts record tóu tóu 'the the' and two record toútou 'this'. The single instance of adjacent homophonous articles in Greek is thus textually suspect and extremely isolated.

10 Ellen Kaisse (p.c.) points out that the Greek dual provides an additional testing ground for the proposal here. Forms of the dual articles are tóo (nominative, accusative) and tóin (genitive, dative). The TLG corpus contains no sequences of tóin tóin, as predicted; but it contains no sequences of tóo tóin either, due to the low occurrence of duals in Greek. The lack of tóin tóin sequences cannot therefore be taken as additional evidence for antihomophony.

11 Ivan Sag (p.c.) suggests that antihomophony might be due to processing factors rather than grammar. He points out that center-embedded sentences in English such as That that John left surprised me worried Mark are noticably more difficult to process than similar sentences in which the complementizers are not homophonous: If that John left surprised me had worried Mark, he would have 
said so. Something about the identity of the complementizers adds to the parsing problem.

The point is well taken. Indeed, if there were any evidence that centerembedded NPs in Greek were difficult to parse, one would want to treat them in a manner analogous to center-embedded sentences in English. But exactly the opposite seems to be the case: whereas (even) putatively easy center-embedded sentences like That that John left surprised me worried Mark are practically nonexistent in English texts, center-embedded NPs are the normal way of constructing possessed NPs in Greek. Furthermore, whereas triple centerembedding seems to be wholly impossible in English (The rat the cat the dog chased ate died), it is clearly not so in Greek, as (4) and (5) demonstrate.

The fact that enter-embedding occurs as frequently as it does in Greek suggests that the prohibition against it in English is not due to the processing abilities of humans but to the grammar of English. The only alternative is to posit that Greek speakers processed language differently than we do today, an unlikely possibility.

12 See Zec (1993), who replaces Hayes' (1989) term Clitic Group with the postlexical phonological word.

13 See Steriade 1982, 1988.

14 Or was. Brett Kessler (p.c.) points out that other particles may intervene between meé 'lest' and ou 'not'. That is, the realis negative is chosen even when the complementizer is not string-adjacent to the negative. This suggests that the use of realis ou 'not' in irrealis clauses headed by meé 'lest' derives from a period of Greek in which complementizer and negative were always adjacent. 
Alternatively, morphologically induced violations of the OCP may simply span longer distances than syntactically induced violations.

15 Adjacent homomorphemic instances of meé, on the other hand, do occur, as predicted.

(i) meè meè meé $\mathrm{m}$ ' anéree tís éimi not not not me ask who I:am 'Don't! don't! don't ask me who I am' $\quad$ S. OC. 210

An anonymous reviewer points out that such cases probably involve distinct phonological phrases. Other such cases occur in Sophocles' Ajax (1191) and in Aristophanes' Wasps (1418) and Peace (927); a similar but post-classical case occurs in Matthew 5.37.

16 Deletion is blocked when an NP-boundary (\#) separates the two no:

(i) no (nominal) + no (genitival )

$\begin{array}{ll}\text { akai no } \# \text { no } & \text { futa } \\ \text { red NOM GEN } & \text { lid } \\ \text { *akai no futa } & \\ \text { 'the red one's lid' }\end{array}$

Poser adds this as a condition to the rule of No-haplology, but we need not stipulate this if the NP-boundary induces a new phonological phrase, as we'd expect from the general phrasing algorithms.

17 ci is otherwise a clitic that means (i) 'us', (ii) 'with her/him', (iii) 'here, there'.

18 Or clitic group. Nespor \& Vogel $(1986,147 \mathrm{ff})$ argue for the latter, noting that, with respect to phonological rules, Italian clitics behave neither as part of a word nor as totally independent words. 


\section{References}

Archangeli, D. (1986). The OCP and Nyangumarda Buffer Vowels. Proceedings of NELS 16. GLSA, University of Massachusetts, Amherst.

Aronoff, M. and R. T. Oehrle (1984) Language sound structure. MIT press.

Bonet, E. 1991. Morphology after syntax: pronominal clitics in Romance. MIT Dissertation.

Borowsky, T. (1987). Antigemination in English Phonology. LI 18, 671-678.

Bulloch, A. W. (1970). A Callimachean refinement of the Greek hexameter: a new "law" and some observations on Greek proclitics. Classical Quarterly 20, 258.

Clark, (1986). OCP Effects in Zulu. Ms., University of New Hampshire.

Clements, G. N. (1988). Towards a Substantive Theory of Feature Specification. NELS 18, 79-93.

Davis, S. (1991). Coronals and the phonotactics of nonadjacent consonants in English. In C. Paradis and J.-F. Prunet (1991). 49-60.

Devine, A.M., and L. Stephens (1978). The Greek appositives: toward a linguistically adequate definition of caesura and bridge. Classical Philology, Vol 73, No 4.

Devine, A.M., and L. Stephens (1981). Bridges in the Iambographers. Greek, Roman and Byzantine Studies, Vol 22, No 4.

Devine, A.M., and L. Stephens (1983). Semantics, syntax, and phonological organization in Greek: aspects of the theory of metrical bridges. Classical Philology, Vol 78, No 1.

Fränkel, H. F. (1960). Wege und Formen frühgriechischen Denkens. München.

Goldsmith, J. A. (1976). Autosegmental phonology. Doctoral dissertation, MIT. Published (1979) New York: Garland.

Goldsmith, J. A. (1984). Meeussen's rule. In M. Aronoff \& R. T. Oehrle (eds.) Language sound structure. Cambridge, MA: MIT press.

Golston, C. (1989). Floating H (and L*) tones in Ancient Greek. Proceedings of the Arizona Phonology Conference, Vol. 3.

Golston, C. (1991) Both Lexicons. Doctoral disseration, UCLA. 
Haas, W. G. de (1988). A formal theory of vowel-coalescence: A case study of Ancient Greek. Doctoral Dissertation, Katholieke Universiteit te Nijmegen. Dordrecht: ICG Printing.

Hayes, B. (1986). Inalterability in CV phonology. Language 62: 321-52.

Hayes, B. (1989). The Prosodic Hierarchy in Meter. In P. Kiparsky and G. Youmans, (eds.) Rhythm and Meter. Orlando: Academic Press.

Inkelas, S. and D. Zec (eds.) (1990). The Phonology-Syntax Connection. University Chicago Press.

Itô, J. and A. Mester. (1986). The Phonology of Voicing in Japanese: Theoretical Consequences for Morphological Accessibility. LI 17, 49-74.

Leben, W. (1973). Suprasegmental phonology. Doctoral dissertation, MIT. New York: Garland.

Leben, W. (1978). The representation of tone. In V. Fromkin (ed.) Tone: a linguistic survey. NewYork: AP.

Lepschy, A.L. and G. Lepschy (1989). The Italian Language Today. London: Hutchinson.

McCarthy, J. J. (1986). OCP effects: gemination and antigemination. LI 17: 207 263.

McCarthy, J. J. (1988). Feature Geometry and Dependency, Phonetica 45, 84-108. McCarthy, J. J. and A. S. Prince. (1993). Prosodic morphology I. ms, University of Massachusetts, Amherst and Rutgers University.

Myers, S. (1987). Tone and the Structure of Words in Shona. Doctoral dissertation, University of Massachusetts, Amherst (distributed by GLSA, University of Massachusetts, Amherst).

Myers, S. (1991). Persistent Rules. Linguistic Inquiry, 22, 315-344.

Nespor, M. \& I. Vogel (1982). Prosodic domains of external sandhi rules. In van der Hulst and Smith (eds.), The Structure of Phonological Representations (Part I), 225-55. Dordrecht: Foris.

Nespor, M. \& I. Vogel (1986). Prosodic Phonology. Dordrecht: Foris.

Paradis, C. and J.-F. Prunet (1991). The Special Status of Coronals: Internal and External Evidence. Phonetics and Phonology, Volume 2. Academic Press. 
Poser, W. (1984). The phonetics and phonology of tone and intonation in Japanese. MIT Dissertation.

Prince, A. S. (1984). Phonology with tiers. In Aronoff and Oehrle (1984).

Prince, A. S. and P. Smolensky. (1993). Optimality theory: Constraint interaction in generative grammar. Ms Rutgers University and University of Colorado, Boulder.

Pulleyblank, D. (1986). Tone in lexical phonology. Dordrecht: Reidel.

Sauzet, P. (1989). L'accent du grec ancien et les relations entre structure métrique et représentation autosegmentale. Langages, 95.

Schein, B. \& D. Steriade (1986). On geminates. Linguistic Inquiry 17: 691-744.

Selkirk, L. (1978). On Prosodic Structure and its Relation to Syntactic Structure. IULC.

Selkirk, L. (1984) Phonology and syntax: the relalation between sound and structure. Cambridge, Mass.: MIT Press.

Selkirk, L. (1986). On derived domains in sentence phonology. Phonology Yearbook 3:371-405.

Selkirk, L. (1990). On the nature of prosodic constituency. In John Kingston and Mary E. Beckman (eds.), Papers in Laboratory Phonology I: Between the Grammar and Physics of Speech. Cambridge: Cambridge University Press.

Smyth, H. W. (1920). Greek Grammar. Cambridge, MA: Harvard University Press.

Stemberger, J.P. (1981). Morphological haplology. Language 57.

Steriade, D. (1982). Greek prosodies and the nature of syllabification. Doctoral dissertation, MIT.

Terada, M. (1986). Minor phrasing in Japanese. MS, University of Masachusetts, Amherst.

Vogel, I. and I. Kenesei. (1990). Syntax and Semantics in Phonology. In Inkelas and Zec (1990). 339-363.

Yip, M. (1988). The OCP and Phonological Rules: A Loss of Identity. LI 19, 65100.

Yip, M. (1993). The interaction of ALIGN, PARSE-Place and ECHO in Reduplication. Paper presented at the Rutgers Optimality Workshop. 
Zec, D. (1993). Rule domains and phonological change. In S. Hargus and E. Kaisse (eds.). 365-405.

Zec, D. and S. Inkelas (1990). Prosodically constrained syntax. In Inkelas and Zec (1990). 365-378.

Zwicky, A. and G. K. Pullum (1986). The principle of phonology-free syntax: introductory remarks. Ohio State University Working Papers in Linguistics 32:63-91.

* This work would not have been possible without extensive free use of the computerized corpus Thesaurus Linguae Graecae. I would like to thank D. J. Mastronarde for helping me get access to this incredible source of data. I would also like to thank Cheryl Chan, Stan Hoffer, Sharon Inkelas, Michael Israel, Paul Kiparsky, Geoff Pullum, John Rickford, Ivan Sag, Tom Wasow, Richard Wiese and Moira Yip for helpful input. A large debt of gratitude to two anonymous NLLT reviewers, two anonymous Phonology reviewers and to Ellen Kaisse, whose careful comments and suggestions were invaluable. All errors or inconsistencies are of course my own.

1 Zec and Inkelas (1990) assume that all syntax-phonology interactions are mediated by prosodic structure. This allows prosody some interaction with syntax but denies it to segmental and sub-segmental phonological information. Thus the term 'prosody' rather than 'phonology' in (2).

2 The constraint seems to generalize to any string of homophonous function words, at least for some speakers. In my speech, for instance, phrases like *the

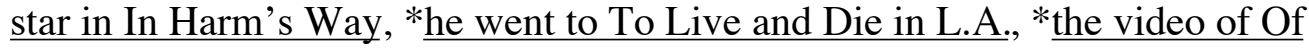
Thee I Sing are ungrammatical without a pause between the offending homophones. 
${ }^{3}$ The second and third homophones may be separated by an adverb:

(a) die die gestern die Blumen gekauft haben those who yesterday the flowers bought have 'those who bought the flowers yesterday'

(b) das das wirklich das Problem ist that this really the problem is 'that this really is the problem'

4 Hayes 1989 was circulated in 1984 as a manuscript; hence the funny chronology of the citations.

5 Tonally dependent words are best analyzed as bearing floating high tones (Sauzet 1989, Golston 1989). There is no segmental, metrical or epigraphic evidence for a prosodic constituent E-Word, as argued for in Steriade 1988.

${ }^{6}$ I use NP as a theory-neutral cover term for DP, N", etc.

${ }^{7}$ Glosses are marked for case, gender and number in that order, using the following abbreviations:

$$
\begin{array}{lll}
\mathrm{a}=\text { accusative } & \mathrm{g}=\text { genitive } & \mathrm{d}=\text { dative } \\
\mathrm{f}=\text { feminine } & \mathrm{m}=\text { masculine } \mathrm{n}=\text { neuter } \\
\mathrm{p}=\text { plural } &
\end{array}
$$

Nominative case and singular number are left unmarked in the glosses.

8 The following abbreviations are used for authors and their works.

A Aristotle

Poet

Ars Poetica

M

Metaphysics

Ar Aristophanes

$\mathrm{Eq}$

Equites

I Isocrates

L Lysias

P Plato

$\begin{array}{ll}\text { A } & \text { Apology } \\ \text { Euth } & \text { Euthyphro } \\ \text { Ph } & \text { Phaedo } \\ \text { Pol } & \text { Politicus ('Statesman') } \\ \text { Rep } & \text { Republic } \\ \text { S } & \text { Sophist } \\ \text { Symp } & \text { Symposium }\end{array}$




$\begin{array}{cll}\mathrm{S} & \text { Sophocles } & \\ & \text { OC } & \text { Oedipus at Colonus } \\ \mathrm{T} & \text { Thucydides } & \text { Peloponnesion Wars } \\ \mathrm{X} & \text { Xenophon } & \\ \mathrm{A} & \text { Anabasis } \\ \mathrm{M} & \text { Memorabilia } \\ & \text { Oec } & \text { Oeconomicus }\end{array}$

${ }^{9}$ The corpus contains one possible exception, from Aristotle's Metaphysics:

t-óu t-óu ónt-os t-ò mèn tó-de éinai the $_{\mathrm{g}: \mathrm{n}}$ the $\mathrm{g}_{\mathrm{g}: \mathrm{n}}$ being $_{\mathrm{g}: \mathrm{n}}$ the $\mathrm{a}_{\mathrm{a}: \mathrm{n}}$ PRT this be $\mathrm{inf}_{\mathrm{i}}$ 'of the (property) of the being of being this' A.M.2.1089a 14

In Aristotle's time, tone and word-division were not marked. What is written here as tóu tóu was merely TOUTOU; this means that it could also be read as the genitive singular deictic toútou 'this':

$$
\begin{aligned}
& \text { toút-ou ónt-os t-ò mèn tó-de éinai } \\
& \text { this } s_{\mathrm{g}: n} \text { being } \mathrm{g}: \mathrm{n} \text { the }{ }_{\mathrm{a}: \mathrm{n}} \text { PRT this be } \text { be }_{\text {inf }} \\
& \text { 'of this being of being this' }
\end{aligned}
$$

The text is found in 4 medieval manuscripts, all of which indicate both tone and word-division: two manuscripts record tóu tóu 'the the' and two record toútou 'this'. The single instance of adjacent homophonous articles in Greek is thus textually suspect and extremely isolated.

${ }^{10}$ Ellen Kaisse (p.c.) points out that the Greek dual provides an additional testing ground for the proposal here. Forms of the dual articles are tóo (nominative, accusative) and tóin (genitive, dative). The TLG corpus contains no sequences of tóin tóin, as predicted; but it contains no sequences of tóo tóin either, due to the low occurrence of duals in Greek. The lack of tóin tóin sequences cannot therefore be taken as additional evidence for antihomophony. 
${ }^{11}$ Ivan Sag (p.c.) suggests that antihomophony might be due to processing factors rather than grammar. He points out that center-embedded sentences in English such as That that John left surprised me worried Mark are noticably more difficult to process than similar sentences in which the complementizers are not homophonous: If that John left surprised me had worried Mark, he would have said so. Something about the identity of the complementizers adds to the parsing problem.

The point is well taken. Indeed, if there were any evidence that centerembedded NPs in Greek were difficult to parse, one would want to treat them in a manner analogous to center-embedded sentences in English. But exactly the opposite seems to be the case: whereas (even) putatively easy center-embedded sentences like That that John left surprised me worried Mark are practically nonexistent in English texts, center-embedded NPs are the normal way of constructing possessed NPs in Greek. Furthermore, whereas triple centerembedding seems to be wholly impossible in English (The rat the cat the dog chased ate died), it is clearly not so in Greek, as (4) and (5) demonstrate.

The fact that enter-embedding occurs as frequently as it does in Greek suggests that the prohibition against it in English is not due to the processing abilities of humans but to the grammar of English. The only alternative is to posit that Greek speakers processed language differently than we do today, an unlikely possibility.

12 See Zec (1993), who replaces Hayes' (1989) term Clitic Group with the postlexical phonological word. 
13 See Steriade 1982, 1988.

${ }^{14}$ Or was. Brett Kessler (p.c.) points out that other particles may intervene between meé 'lest'and ou 'not'. That is, the realis negative is chosen even when the complementizer is not string-adjacent to the negative. This suggests that the use of realis ou 'not' in irrealis clauses headed by meé 'lest' derives from a period of Greek in which complementizer and negative were always adjacent.

Alternatively, morphologically induced violations of the OCP may simply span longer distances than syntactically induced violations.

15 Adjacent homomorphemic instances of meé, on the other hand, do occur, as predicted.

(i) meè meè meé $\mathrm{m}$ ' anéree tís éimi not not not me ask who I:am

'Don't! don't! don't ask me who I am' $\quad$ S. OC. 210

An anonymous reviewer points out that such cases probably involve distinct phonological phrases. Other such cases occur in Sophocles' Ajax (1191) and in Aristophanes' Wasps (1418) and Peace (927); a similar but post-classical case occurs in Matthew 5.37.

${ }^{16}$ Deletion is blocked when an NP-boundary (\#) separates the two no:

(i) no (nominal) + no (genitival )

$\begin{array}{ll}\text { akai no \# no } & \text { futa } \\ \text { red NOM GEN } & \text { lid } \\ \text { *akai no futa } & \\ \text { 'the red one's lid' }\end{array}$


Poser adds this as a condition to the rule of No-haplology, but we need not stipulate this if the NP-boundary induces a new phonological phrase, as we'd expect from the general phrasing algorithms.

17 ci is otherwise a clitic that means (i) 'us', (ii) 'with her/him', (iii) 'here, there'.

${ }^{18}$ Or clitic group. Nespor \& Vogel $(1986,147 \mathrm{ff})$ argue for the latter, noting that, with respect to phonological rules, Italian clitics behave neither as part of a word nor as totally independent words. 